\title{
PENGARUH PEMBERIAN STIMULASI TUMBUH KEMBANG ANAK PADA USIA 36 BULAN PADA An. K Di KELURAHAN SUMBEREJO KEMILING BANDAR LAMPUNG
}

DOI: https://doi.org/10.33024/jkpm.v4i4.2850

\author{
Setiawati ${ }^{1 *}$, Reni Aprilia $B^{2}$, Linawati Novikasari ${ }^{3}$ \\ ${ }^{1,3}$ Dosen Keperawatan Universitas Malahayati Bandar Lampung \\ ${ }^{2}$ Mahasiswa Program Studi IImu Keperawatan Universitas Malahayati
}

Disubmit: 13 Juni 2020 Diterima: 01 Agustus 2021 Diterbitkan: 02 Agustus 2021

Email Korespondensi: Setiawati@malahayati.ac.id

\begin{abstract}
ABSTRAK
Keterlambatan perkembangan anak pada aspek tertentu saat ini masih menjadi slah satu masalah kesehatan bagi anak di Indonesia yang dapat mengurangi kualitas sumber daya manusia di masa mendatang. Melakui pendekatan famly cantered-care orang tua anak dapat melakukan intervensi dini terhadap masalah keterlambatan perkembangan anak sebagai upaya pencegahan terhadap keterlambatan perkembangan anak lebih lanjut dengan pemberian stimulasi perkembangan terarah selama 2 minggu. Stimulasi adalah perangsangan dari luar lingkungan anak dimana dengan mengasah kemampuan anak secara terus-menerus kemampuan anak dimana dengan mengasah kemampuan anak secara terus-menerus kemampuan anak akan meningkat.
\end{abstract}

Kata kunci : Anak Praskolah, Keterlambatan Perkembangan Anak, Stimulasi Perkembangan

\begin{abstract}
The delay in childern development on specific aspect is still on of the health problem for Indonesia children which can reduce the human resources quality in the future. Throught a family centered-care approach, parents will be able to do early intervention for the delay in children development problem prevention against further delay in children development with a directional development stimulation for 2 weeks. Stimulation was an external environment stimulation in ability.
\end{abstract}

Keyword: preschool Children, Children's Delay Development, Development Stimulation 


\section{PENDAHULUAN}

Masa usia dini adalah masa yang sangat menentukan bagi perkembangan dan pertumbuhan anak selanjutnya karena merupakan masa peka dan masa emas dalam kehidupan anak. Rentang anak usia dini dari lahir sampai usia 6 tahun adalah usia kritis sekaligus strategis untuk menumbuh kembangkan berbagai kemampuan, kecerdasan, kemampuan fisik, kongnitif, bahasa,sosio-emosional, dan spiritual. Hal ini mengisyaratkan bahwa semua pihak perlu memahami pentingnya masa usia dini untuk optimalisasi pertumbuhan dan perkembangan (Yamin \& Sabri, 2013).

Balita di Indonesia berjumlah 23,7 juta jiwa atau sekitar 10,4\% dari total penduduk Indonesia (IDAI, 2008). Namun hingga saat ini, angka gangguan perkembangan anak di Indonesia masih cukup tinggi. Profil kesehatan Indonesia tahun 2011 menunjukan bahwa 13-18\% anak balita mengalami keterlambatan perekmbangan (Usman, et al, 2014). Berdasarkan penilitian yang dilakukan di Rumah Sakit Anak dan Bunda Harapan Kita, terdapat $30,9 \%$ anak mengalami keterlambatan perkembangan (Tjandrajani, et al., 2012). Sementara hasil skrining perkembangan anak yang dilakukan Depkes RI pada 30 provinsi didapatkan data gangguan perkembangan pada anak sebesar 45,12\% (Christiari, et al.,2013). Sementara penelitian yang dilakukan di Bandung menyebutkan adanya gangguan sosialisasi dan kemandirian pada anak sebesar 2,92\% (Gunawan, et al., 2016).

Menurut Depkes RI (2005) mengatasi gangguan perkembangan motorik pada anak dengan melalui penilaian pertumbuhan dan perkembangan dapat dilakukan sedini mungkin sejak anak dilahirkan. Melalui deteksi dini dapat diketahui penyimpangan tumbuh kembang anak secara dini, sehingga upaya, pencegahan, stimulasi, penyembuhan serta pemulihan dapat diberikan dengan indikasi yang jelas pada masa-masa kritis proses tumbuh kembang. Penilaian pertumbuhan fisik dan perkembangan meliputi dua hal pokok, yaitu penilaian pertumbuhan fisik dan penilaian perkembangan. Alat yang digunakan untuk mengetahui gangguan perkembangan anak yaitu: Kuisioner Pra Skrining Perkembangan (KPSP) adalah untuk mengetahui bagaimana perkembangan anak sesuai dengan umurnya dan dapat dijadikan sebagai alat deteksi dini di tingkat posyandu, dan Denver Development Skrining Test (DDST II) adalah mengarahkan kepada perbandingan kemampuan atau perkembangan anak dengan kemampuan anak lain yang seumurnya (Suistyawati, 2014).

\section{MASALAH}

Alasan saya memilih ditempat penyuluhan kesehata tentang stimulasi tumbuh kembang anak dan memberikan terapi tentang pengaruh pemberian stimulasi tumbuh kembang anak di Kelurahan Sumberejo, kemiling ialah karena pada An. K memiliki masalah gangguan tumbuh kembang, dimana tujuan umum dalam kegiatan ini diharapkan pemberian stimulasi tumbuh kembang anak dapat membuat An.K menjadi lebih baik dari pada sebelum dilakukan stimulasi tumbuh kembang, dan tujuan khusus dalam kegiatan yaitu asuhan keperawatan, telaah jurnal untuk menentukan intervensi, evaluasi hasil aplikasi intervensi, perbandingan hasil intervensi pemberian stimulasi tumbuh kembang anak, berikut gambar lokasi kegiatan ; 


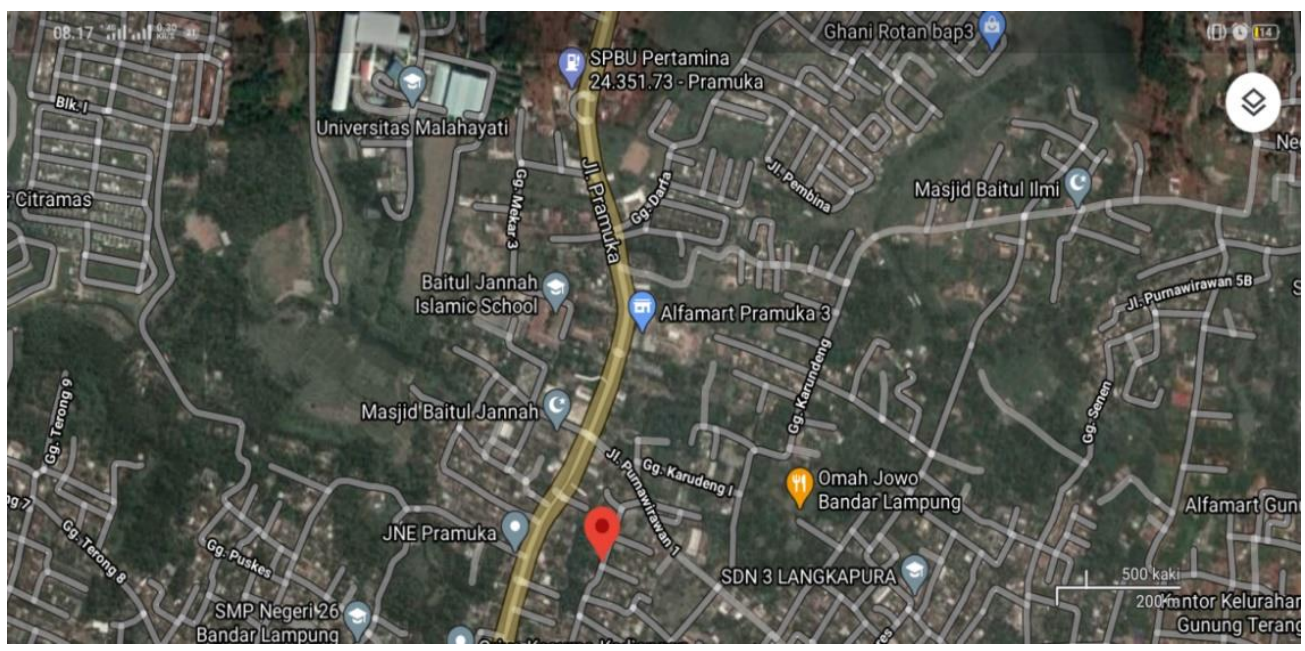

Gambar 2.1 Lokasi penyuluhan dan memberikan stimulasi tumbuh kembang anak

3. METODE

1. Tujuan Persiapan

Tujuan persiapan dari kegiatan adalah pembuatan pre planning, persiapan penyajian lembar balik dan penyuluhan, tempat, alatalat lainnya disiapkan oleh peneliti. Pembuatan lembar balik dibuat pada tanggal 26 april 2020, dan pada tanggal 28 april 2020 dilakukan penyuluhan, pemeriksaan tumbuh kembang anak serta memberikan stimulasi tumbuh kembang anak.

2. Tahap pelaksanaan

Kegiatan ini dengan pemberitahuan kepada klien dan dilanjutkan penyuluhan, pengkajian serta melakukan pengecekan penyimpangan tumbuh kembang, dan penyimpangan mental emosional yang digunkan dengan lembar ceklist, serta melakukan stimulasi tumbuh kembang pada anak.

3. Evaluasi

a. Struktur

Peserta hadir 2 orang yaitu ibu dan anak. Setting tempat sudah sesuai dengan rencana dan perlengkapan yang dilakukan untuk penyuluhan sudah tersedia dan sudah digunakan sebagaimana mestinya. Peran peneliti sebagai moderator, notulen, observer, dan juga fasilitator. Penggunaan bahasa yang diperaktekkan sudah komunikatif dalam penyampaian, klien dapat memahami dan dapat memperaktekan kembali yang telah dilakuka pemberian stimulasi.

b. Proses

Pelaksanaan kegiatan dilaksanakan pukul 09.00 s/d 09.45 WIB. Sesuai dengan jadwal yang sudah ditentukan. 


\section{HASIL DAN PEMBAHASAN}

Metode pelaksanaan pemberian stimulasi tumbuh kembang anak dilaksanakan pada tanggal 28 april 2020 s/d tanggal 11 mei 2020. Penelitian dilakukan selama 14 hari, setelah dilakukan pemberian stimulasi selama 14 hari didapatkan anak telah memiliki perubahan yang positif. Berikut pelaksanaan penyuluhan, pengecekan deteksi dini penyimpangan tumbuh kembang, dan penyimpangan mental emosional
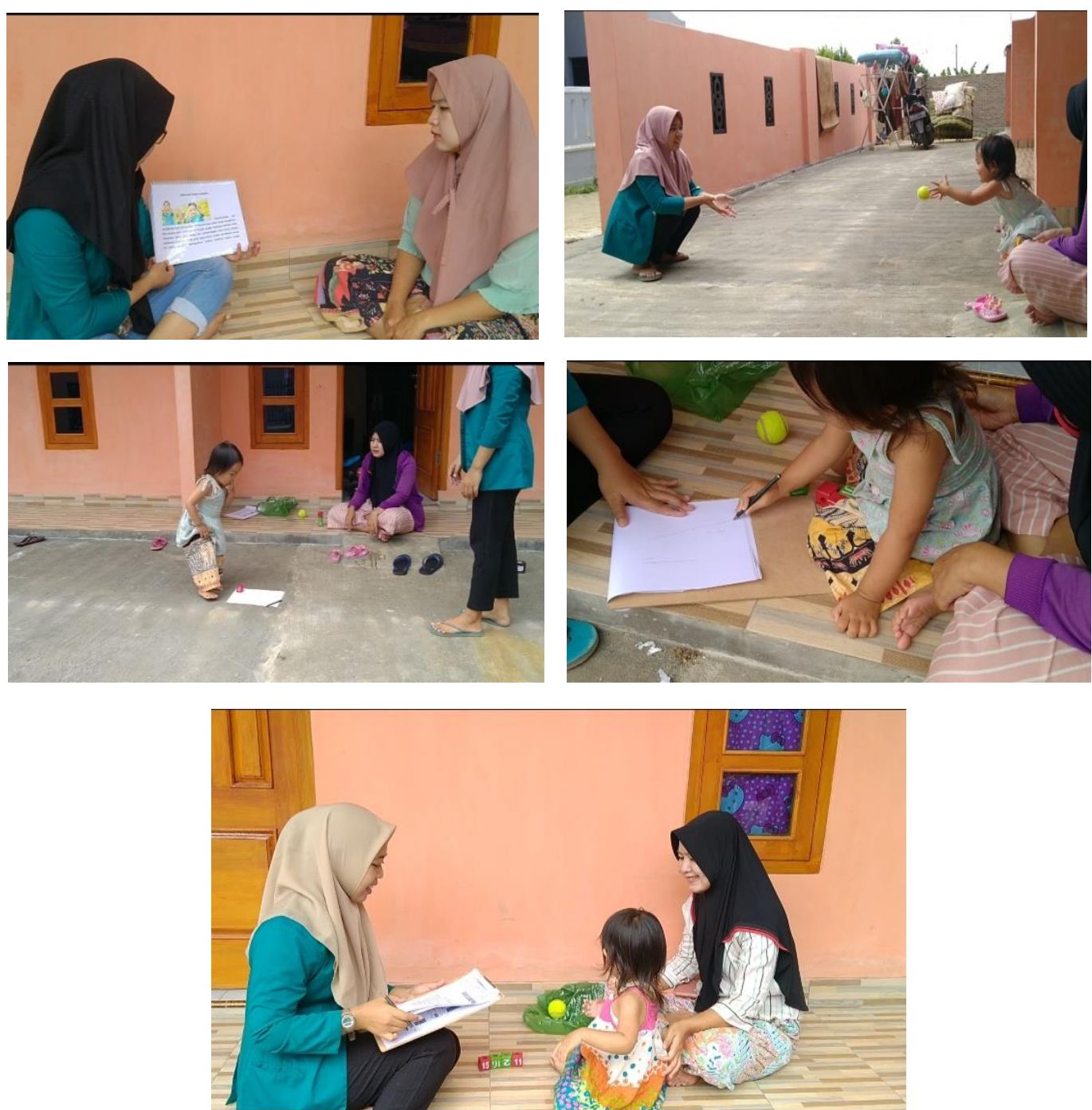

Gambar 4.1 pelaksanaan penyuluhan, pengecekan deteksi dini penyimpangan tumbuh kembang, dan penyimpngan mental emosional pada anak

\section{KESIMPULAN}

Balita di Indonesia berjumlah 23,7 juta jiwa atau sekitar 10,4\% dari total penduduk Indonesia (IDAI, 2008). Namun hingga saat ini, angka gangguan perkembangan anak di Indonesia masih cukup tinggi. Profil kesehatan Indonesia tahun 2011 menunjukan bahwa 13-18\% anak balita mengalami keterlambatan perekmbangan (Usman, et al, 2014). Berdasarkan penilitian yang dilakukan di Rumah Sakit Anak dan Bunda Harapan Kita, terdapat 30,9\% anak mengalami keterlambatan perkembangan (Tjandrajani, et al., 2012). Sementara hasil skrining 
perkembangan anak yang dilakukan Depkes RI pada 30 provinsi didapatkan data gangguan perkembangan pada anak sebesar 45,12\% (Christiari, et al.,2013). Sementara penelitian yang dilakukan di Bandung menyebutkan adanya gangguan sosialisasi dan kemandirian pada anak sebesar 2,92\% (Gunawan, et al., 2016).

Stimulasi tumbuh kembang adalah kegiatan merangsang kemampuan dasar anak usia 0-6 tahun agar berekmabng secara optimal. Setiap anak perlu mendapatkan stimulasi rutin secara dini dan terus-menerus pada stiap kesempatan. Stimulasi perkembangan anak dilakukan oleh ibu,ayah, pengasuh anak, anggota keluarga lainnya dan kelompok masyarakat dilingkungan sekitarnya. Selain itu, secara otomatis anak juga "terstimulasi" oleh teman bermainnya ketika dalam permainan yang diatur oleh " sistem permainan dan interaksi" yang bermanfaat juga untuk proses tumbuh kembangnya.

Kemampuan dasar anak yang dirangsang dengan stimulasi terarah adalah kemampuan gerak kasar, kemampuan gerak halus, kemampuan bicara dan bahasa, serta kemampuan sosialisasi dan kemandirian (Ary Sulistyawati, 2014).

\section{DAFTAR PUSTAKA}

Ari Sulistyawati. (2014). Deteksi Tumbuh Kembang Anak . Jakarta : Salemba Medika.

Kementerian Kesehatan RI. (2016). Stimulasi, Deteksi dan Intervensi Dini Tumbuh Kembang Anak . Bakti Husada.

Yuliastati \& Amelia. (2016). Modul Bahan Ajar Keperawatan Anak. Kementerian Kesehatan RI.

Najmarani. (2018). Hubungan Tingkat pendapatan Keluarga, Tingkat Pengetahuan Ibu tentang Stimulasi Perkembangan Anak, dan Tingkat Pendidikan Ibu dengan perkembangan sosial anak balita di kota madiun. Naskah Publikasi . google scholar . diambil pada tanggal 13 april 2020.

Nurhasanah. (2015). hubungan tingkat pengetahuan ibu tentang stimulasi dengan perkembangan motorik anak usia 1-3tahun di posyandu teratai 1 desa bangujiwo. Naskah Publikasi . diambil pada tanggal 14 april 2020.

Soetjiningsih. (2016). Tumbuh Kembang Anak . Edisi 2 . Jakarta : EGC

Telly Katharina. (2016). Hubungan antara pengetahuan ibu dengan sikap terhadap tumbuh kembang anak usia 0-36 bulan . Jurnal KebidananISSN 2252-8121. Volume 6 Nomor 2 . google scholar . diambil pada tanggal 14 april 2020.

Tim pokja SDKI DPP PPNI. (2017). Standar Diagnosa Keperawatan Indonesia . Definisi dan Indikator Diagnotik . jilid 1 . Jakarta : Dewan Pengurus Pusat Persatuan Perawat Nasional Indonesia. 